\title{
TERRITORIAL VARIATIONS OF RECENT ELECTIONS RESULTS IN BOSNIA AND HERZEGOVINA AS A FACTOR OF ITS MODERN POLITICAL-GEOGRAPHIC DEVELOPMENT
}

DOI: http://dx.doi.org/10.18509/GBP.2015.42

UDC: $342.847:[911.3: 32(497.6), 19 “ 6$

\author{
Dr. Sc. Ranko Mirić, assistant professor \\ Boris Avdić, MA, assistant, PhD student \\ Amra Banda, MA, assistant, PhD student \\ Amina Sivac, BA, assistant \\ University of Sarajevo, Faculty of Science, Department of Geography - Bosnia and Herzegovina
}

\begin{abstract}
The social development of Bosnia and Herzegovina largely depends on the level of success in overcoming the existing political problems, which are originated in the recent or more distant past. The structure of political subjects and election results within the country clearly reflects a post-conflict state in society that is primarily divided by ethnical, and secondarily by ideological, regional and social lines, generated in the ambience of an extremely complex political-territorial structure of Bosnia and Herzegovina. As a branch of political geography which among other things studies ways to define electoral units and spatial models of variations of voters behavior, electoral geography has emphasized competency in explaining these phenomena.

This paper is thematizing a geographical component of the factual political situation in Bosnia and Herzegovina, i.e. spatial differentiation of voting affinities towards existing political options through the analysis of a complicated electoral system and election results for the highest government level - Parliamentary Assembly of Bosnia and Herzegovina. Considering that electoral geography of Bosnia and Herzegovina was completely neglected so far, results of this research can be used as a foundation for its further development. The selected data from the results of political subjects at the recent general elections were analyzed from the aspect of their election results at the local level, in municipalities and cities. In this way, territorial distribution of voter preferences and its general patterns are clarified.
\end{abstract}

Keywords: Electoral Geography, electoral unit (constituency), voters behavior, political subject.

\section{INTRODUCTION}

According to Cvrtila, Electoral Geography is a discipline engaged in analyzing the organization, implementation and results of elections and it is part of Political Geography. First works in this field were published in the early 20th century. Since then, this branch of Political Geography has developed to the greatest extent in the countries with a longer tradition of democratic multiparty elections. [1] With the collapse of the single party systems in Eastern Europe at the beginning of the 1990s, an opportunity but also a need presented itself for the development of this discipline in this part of the world too. 
However, no major breakthroughs were achieved in South Eastern Europe in terms of scientific research of spatial electoral phenomena, which holds true for Bosnia and Herzegovina in particular. That is a paradoxical fact, since the complex political situation in a number of countries of this region can be explained through the results obtained by analyzing the spatial electoral variations.

The purpose of this paper is to present the current status of geography of voting in Bosnia and Herzegovina and thus lay the foundation for some more complex research in this domain in the future. Glassner believes that this branch of geographical science seeks to explain the patterns of voting used in a specific election event or in a longer succession of election events. In addition, he maintains that the emphasis is placed on statistical methods and he calls into question the convenience of the trend of exclusion of cartographic representations in favor of statistics and mathematical formulas. [3] This tendency could completely defeat the position of geography in this type of research. Therefore, geographers must insist on taking a more intensive cartographic approach in this domain. The major products of this work are indeed nothing less than geographic maps which visually very clearly reflect the voting affinities in their spatial dimension. Thus, the analytical and statistical methods have been incorporated in the cartographic method.

\section{DEVELOPMENT OF POLITICAL AND ELECTORAL SYSTEMS IN BOSNIA AND HERZEGOVINA}

The beginning of the last decade of the 20th century brought to an end a political monopoly of the League of Communists of Yugoslavia in the Socialist Federative Republic of Yugoslavia, of which Bosnia and Herzegovina was part. A number of new political parties were established and briefly after that, near the end of 1990, the first multi-party elections were held. The introduction of a multi-party system is often identified with democratization, but some analysts nevertheless tend to disagree with that notion. Dejanović believes that democratization in the case of Bosnia and Herzegovina and neighboring countries would mean the abandonment of the existing partitocracy or false democracy system and the beginning of a transitional phase in which the society should: (1) redefine the party and political systems and build up, inter alia, the party capacities capable of better representing the public interests; (2) create the systematic conditions required for the existence of civil activism; (3) strengthen a participatory component of the political system, and; (4) ensure measurable progress in democratization. [2] Consequently, one should have in mind that this work is thematizing a multi-party system in Bosnia and Herzegovina, but not necessarily democratization as well.

Klemenčić singled out at some point the following five milestones that marked the transition from a single-party to a multi-party system in the neighboring Croatia: (1) a dramatic change in the European countries of the socialist block; (2) support provided to these changes by the European West; (3) the crisis and the collapse of the political and economic system of Yugoslavia; (4) a number of marked inter-ethnic antagonisms, and; (5) the sudden emergence of a number of parties within a short period of time after the 45-year rule of a single political party. [4] Practically, the same conditions also applied to Bosnia and Herzegovina, with the only exception that the inter-ethnic antagonisms took on an even greater importance because of the highly heterogeneous ethnic composition of the then Federal Republic, in terms of both numbers and spatial distribution. Even the 
results of the first multiparty elections were popularly called the Population Census. [2] The Party of Democratic Action (SDA) won these elections by a clear margin in the most of municipalities with a Bosniak (Muslim) majority, as did the Serb Democratic Party (SDS) in municipalities with a Serb majority, and the Croat Democratic Union (HDZ) in municipalities with a Croat majority. A non-ethnic option was the most successful in only three municipalities: Tuzla, Novo Sarajevo and Vareš.

The clear lack of concord among the three winning national parties concerning the future of Bosnia and Herzegovina led to an armed conflict in the period from 1992 to 1995. The SDA advocated a disassociation of Bosnia and Herzegovina from Yugoslavia, similar to what the HDZ did. On the other hand, the SDS firmly supported a view that Bosnia and Herzegovina, or at least the part of the same country where Serbs made up a significant share of the population, must remain within the boundaries of the then Yugoslavia, having opposed the outvoting of the Serbs by the other two ethnic groups. Later on, there occurred a disagreement also between the SDA and HDZ. The war ended with the signing of the Dayton Peace Agreement in 1995, by virtue of which Bosnia and Herzegovina got a new constitution and a highly complex arrangement of its political and territorial system. The Republika Srpska and the Federation of Bosnia and Herzegovina became the integral parts of the new state, while Brčko District was established at a later point. The Federation of Bosnia and Herzegovina was divided into 10 cantons, of which five were with absolute Bosniak majority, three with Croatian majority, and two ethnically mixed ones. The three ethnic political parties continued their absolute dominance in the postwar period until 2000, when major changes occurred in terms of pluralization and fragmentation of the political arena, but a clear tri-ethnic division of the electorate remained in place.

Complexity of the post-war political and territorial structure of the state is accompanied by a complex electoral system. The general elections are held to elect three members of the Presidency (one from each constituent people), the delegates to the Parliamentary Assembly of Bosnia and Herzegovina, the delegates to the parliaments of both entities and the delegates to the legislatures or assemblies of all 10 cantons in the Federation of Bosnia and Hercegovina. The theme of this research paper is exclusively the state level of legislative authority, i.e. the Parliamentary Assembly of Bosnia and Herzegovina. It has only 42 delegates due to the fact that much greater political power is consolidated at the lower, entity level. The number of delegates coming from each entity is fixed -28 from the Federation of Bosnia and Herzegovina and 14 from the Republika Srpska. Under the current territorial arrangement, the Federation is divided into five electoral units (constituencies), each of them covering the territory of two cantons. The Republika Srpska is divided into three electoral units by the criterion of approximate population balance. In both entities, there is in force a proportional system of translation of votes into the delegate mandates. Each electoral unit provides a specific number (3-6) of direct mandates, whereas the remainder of the Parliamentary Assembly is filled with the compensatory mandates ( 7 from the Federation of Bosnia and Herzegovina and 5 from the Republika Srpska). This dual method of acquisition of mandates is in existence in order not to grant a preferential treatment to those political subjects whose electorate is scattered across the entities, including those whose voters are concentrated in the specific electoral units (constituencies). 


\section{SPATIAL PATTERNS OF VOTERS BEHAVIOR}

Results of the 2014 General Elections show a continued trend of fragmentation of the electorate in Bosnia and Herzegovina. Together with Lithuania, Bosnia and Herzegovina is currently the only country in Europe without even a single political party that has more than $20 \%$ of support among the voters. The reason for this lies in the continued and even more radical ethno-political divisions that take place in society, but also in the level of dissatisfaction with the existing relevant political parties that is present among most citizens. The consequence of this situation is the difficult formation and functioning of the executive branch of authority. The voter turnout rate in the last elections was about $54 \%$. The number of valid ballots in the voting for the Parliamentary Assembly of Bosnia and Herzegovina was $1,630,920$ or $49.7 \%$ of the total number of registered voters. The number of political subjects nominating their candidates for this level of government was 28, among which 12 of them managed to enter the Parliament. In the section that follows, this paper analyzes the spatial characteristics of the election results of these political parties.

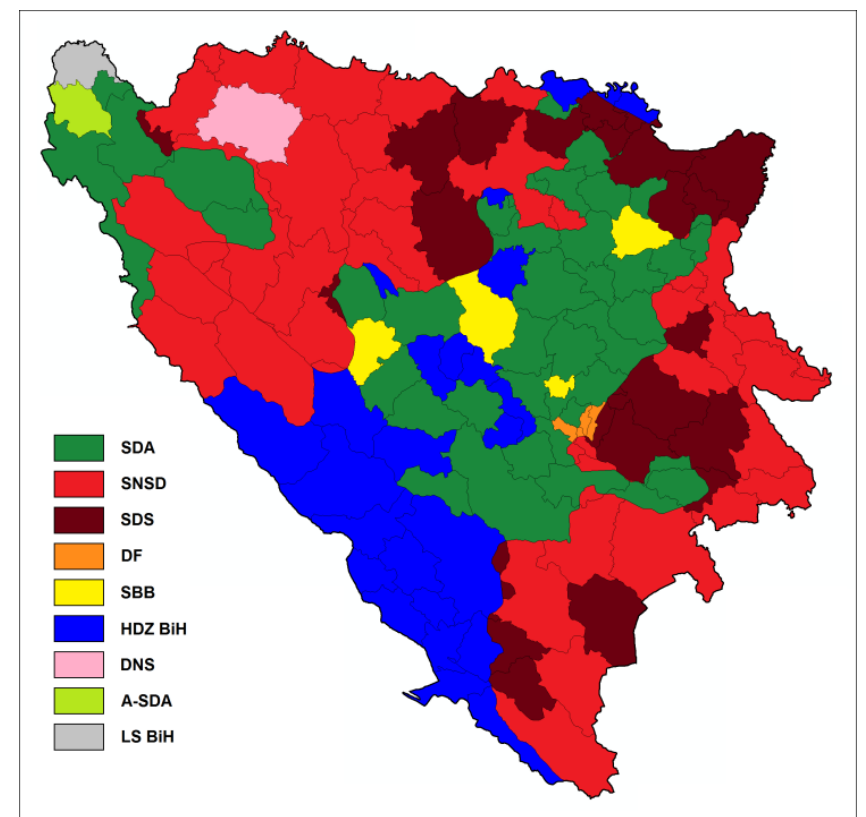

Figure 1: Voting preferences by municipalities in the 2014 elections

(Source of data: http://www.izbori.ba/Potvrdjeni2014/Finalni/ParlamentBIH/Default.aspx)

The Party of Democratic Action (SDA) is the party that achieved the best results in the last elections. It is a center-right party, whose political platform is based on the representation of Bosniak national interests, conservatism, its insistence on the territorial integrity of Bosnia and Herzegovina and aspirations towards European integration. It won $18.4 \%$ of the valid votes at the state level, which means that it has experienced a considerable increase compared with the preceding elections, when its voting result was $13.1 \%$. The number of mandates won by this party has ascended from 8 to 10 . Thus, it has become a winning party with the weakest support in Europe. As anticipated, it got far more support in the Federation of Bosnia and Herzegovina then in the Republika Srpska, where it won only one seat. Since it is focused almost exclusively on the Bosniak electorate, the territorial variations of its election results are consistent with the spatial distribution of the Bosniak population. Most support for this political party comes from Bosniak monoethnic communities, particularly those in rural municipalities such as Pale $(\mathrm{FBiH})$, Sapna, Teočak and Bužim, where its support was over 50\%. In addition to these 
municipalities, a traditional stronghold of this party is the coal-mining municipality of Banovići (76.9\%). In urban areas, the situation for this party has slightly deteriorated, since it failed to win in any of the five major cities.

The Alliance of Independent Social Democrats (SNSD) is nominally a party of social democratic (center-left) orientation, but, over the recent years, it has become recognized by its hard line views on the preservation and political strengthening of the Republika Srpska, and even its secession from Bosnia and Herzegovina. As such, it seems to be acceptable only to the population from among Serb people. Indeed, for the last three successive election periods, the SNSD has been the strongest political party in the Republika Srpska, although its popularity is steadily declining - from $19.1 \%$ in 2006, to $16.9 \%$ in 2010 and ultimately to $15.6 \%$ in 2014 (6 seats). Its dominance is particularly pronounced in the western part of the Republika Srpska, i.e. in the municipalities gravitating towards City of Banja Luka. The popularity of this party is slightly lower in the less economically developed eastern part of this entity, and particularly in the northeast part, where the local dissatisfaction with the response of SNSD authorities to the flooding disaster in the spring of 2014 has further contributed to the loss of support (e.g. in Bijeljina). In the other entity, the more significant result was achieved only in the municipalities with a greater share of Serb population: Drvar, Bosansko Grahovo, Bosanski Petrovac and Glamoč.

The Serb Democratic Party (SDS) associates its action almost exclusively with the territory of the Republika Srpska. It belongs to the right side of political spectrum, and in the 1990s it was considered as the main political party representing the collective interests of Bosnian Serbs and strongly opposing the independence of Bosnia and Hercegovina. However, its main characteristic since 2006 has been the opposition activity and the confrontation against the SNSD at the level of the Republika Srpska. In the 2014 elections, it achieved a better result than four years earlier $(8.4 \%$ in $2010-13 \%$ in 2014). Thus it has become the third most successful party by the criterion of the number of votes won at the state level, winning the total of five seats. As it did not nominate its candidates in the Federation of Bosnia and Herzegovina at all, it received all its votes in the Republika Srpska only. Unlike the SNSD, this party enjoys the greatest support in the northeastern parts of this entity.

The Democratic Front (DF) is a newly created political party, whose relatively successful voting result (9.2\% and 5 seats) is based on the popularity of its leader. It advocates the civil and secular concepts of constitutional order of Bosnia and Herzegovina, a deconstruction of the current state system and the establishment of a decentralized regionalization, which must not have any ethnic background. As such, it is seems to be unacceptable for most voters in the Republika Srpska, and consequently this party did not nominate its candidates in the constituencies of that entity at all. In the territory of the Federation of Bosnia and Herzegovina, it has received most of its votes in the urban and predominantly Bosniak areas. As a result, it achieved its best score (above 25\%) in Sarajevo, particularly in Municipality of Novo Sarajevo (above 30\%), which is probably due to the neighborhood effect. A very good score was achieved also in Tuzla and in parts of the Una-Sana Canton.

The Alliance for a Better Future (SBB) is one of the parties that has achieved a competitive rate of growth compared with the previous general elections (from $7.9 \%$ to $8.7 \%$ ), by winning 4 seats. It is defined as a center-right party with highly prominent secular viewpoints. Its main electorate body is made of Bosniaks; so it marked the SDA as its main rival. As it is already pointed out, the rural areas are the main stronghold of 
the SDA; therefore, SBB was more oriented towards the cities. They are the party that achieved the best score by the criterion of the number of votes won in two large cities Tuzla and Zenica (above 25\%), but also in the towns of Breza and Donji Vakuf. It did not nominate its candidates in the constituencies of the Republika Srpska, while the number of votes it received in the ethnically dominant Croat areas was only symbolic.

The Croat Democratic Union of Bosnia and Herzegovina (HDZ BiH) is the largest party bringing together the Croat electorate in Bosnia and Herzegovina. Considering that the Croats are the smallest constituent people in the state and that there is an overwhelming fear of political marginalization among the members of this people, the HDZ BiH did not lose its status as the strongest party of Bosnian Croats in any of the multi-party elections so far. During the last elections, there was a marked tendency of reinforcing the position of this party (7\% and 3 seats in $2010-7.5 \%$ and 4 seats in 2014), although it should be noted that it participated in these elections in coalition with four smaller Croat parties. Unlike the previous elections, in the 2014 elections the HDZ BiH won the greatest number of votes in all municipalities with Croat majority, but also in some municipalities with a heterogeneous ethnic structure. Municipalities that have the highest percentage of Croat population correspond to the municipalities in which the HDZ won the highest percentage of votes, which pertains primarily to the area of Western Herzegovina, South-Western Bosnia, as well as parts of Central Bosnia and Posavina in the north. In the Republika Srpska, it has achieved a very modest score.

The Social Democratic Party (SDP) is the major loser of the 2014 elections. Four years earlier, it was the winner with $17.3 \%$ of votes and 8 seats, whereas in the current elections it won only $6.7 \%$ of votes and 3 seats. The SDP defines itself as a multi-ethnic, proEuropean and secular center-left party. Even though it keeps the record of somewhat better results among the Serb and Croat populations compared with other Sarajevo-based parties, its primary electorate body is made of Bosniak population. Traditionally, it is relying on urban areas and the working class citizens, but the emergence of the DF has contributed considerably to the sharp decline of its election success in these areas. The best result it achieved was in Tuzla Canton and the northern part of Zenica-Doboj Canton. Along with the SDA, it was the only party that participated in the elections in all eight electoral units, while in the Republika Srpska it has achieved slightly better results only in the municipalities where repatriation of Bosniak refugees was conducted more successfully.

Five political subjects have each won one seat in the Parliamentary Assembly. Most votes among them (3.1\%) have been won by a coalition of the Democratic Progress Party and the National Democratic Movement (PDP-NDP). This coalition from the Republika Srpska is characterized by a somewhat more temperate rhetoric concerning the staterelated issues and by its opposition activity against the SNSD. Due to the neighborhood effect it has recorded a very favorable result in some municipalities in the Republika Srpska (e.g. Foča). The fourth parliamentary party based in the Republika Srpska, the Democratic People's Alliance (DNS) has won 1 seat which is due primarily to a solid result achieved in its stronghold, the City of Prijedor, although it has won only $2.3 \%$ of votes at the state level. The Croat Democratic Union 1990 (HDZ 1990) was established as a result of separation from the HDZ BiH mother party and can be considered as the only serious opposition to the latter party in the Croat electorate. It has won $2.5 \%$ of votes thanks to a decent result in the municipalities such as Prozor-Rama, Usora, DomaljevacŠmac, etc. Due to the fierce rhetoric of opposition against the Dayton-made structure and organization of the country, the Bosnian-Herzegovinian Patriotic Party (BPS) 
managed to return to the Parliament, by winning $2.3 \%$ of votes and it did so almost exclusively in the predominantly Bosniak areas. The Party of Democratic Activity (ASDA) entered the Parliament with only $1.4 \%$ of votes, thanks to a solid result achieved in Una-Sana Canton, particularly in Cazin Municipality. Judged by its work, it can be called a regional, Bosniak and conservative party.

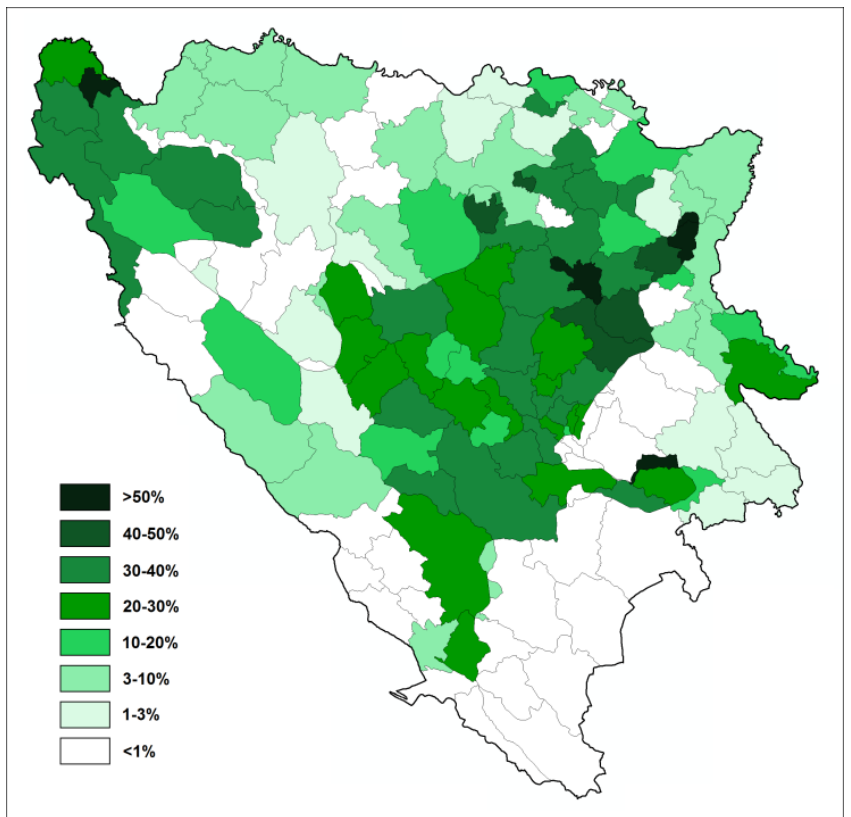

Figure 2: Spatial variations in SDA voter support

(Source of data: http://www.izbori.ba/Potvrdjeni2014/Finalni/ParlamentBIH/Default.aspx)

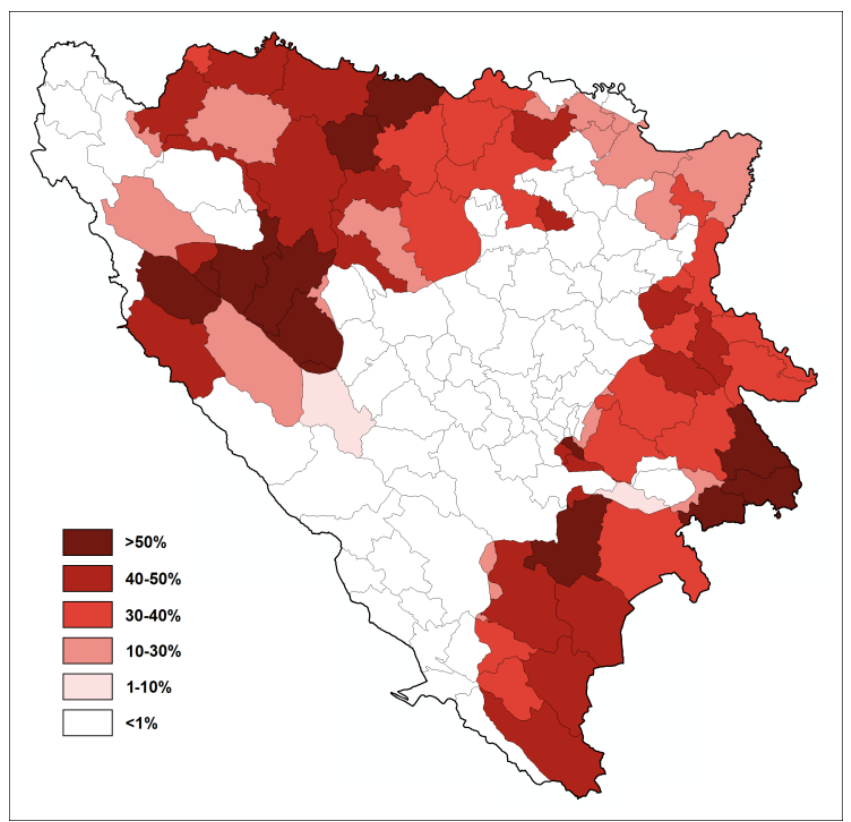

Figure 3: Spatial variations in SNSD voter support

(Source of data: http://www.izbori.ba/Potvrdjeni2014/Finalni/ParlamentBIH/Default.aspx) 


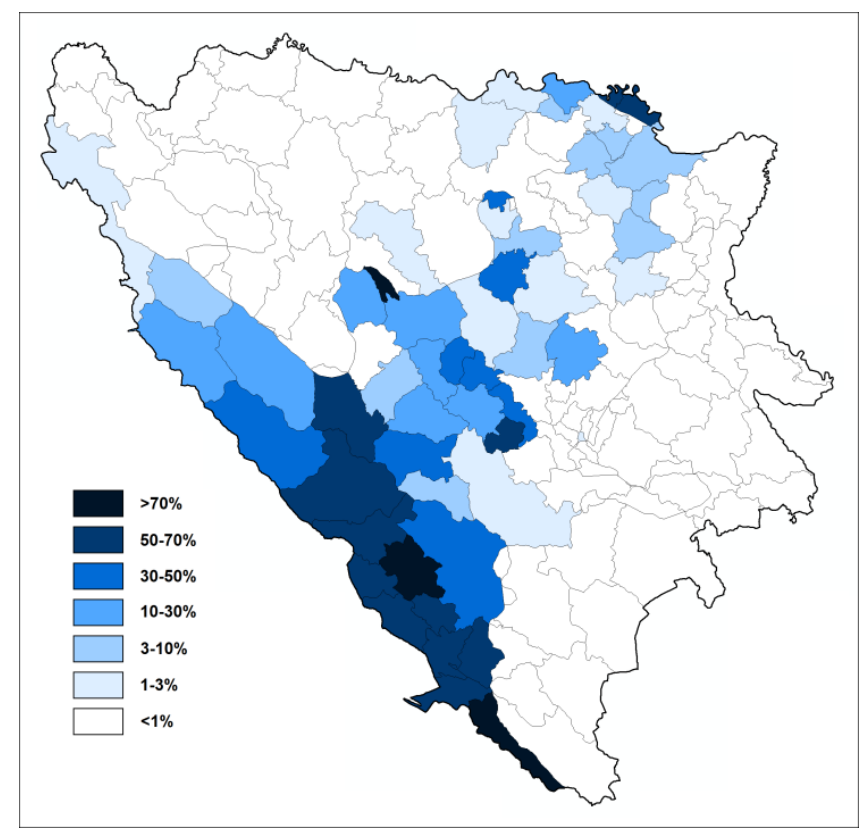

Figure 4: Spatial variations in HDZ BiH voter support (Source of data: http://www.izbori.ba/Potvrdjeni2014/Finalni/ParlamentBIH/Default.aspx)

\section{CONCLUSION}

The most important determinant of electoral geography of Bosnia and Herzegovina still remains deeply rooted ethno-political division, which is further boosted by interethnic tensions. Six out of twelve current parliamentary political parties (SDA, DF, SBB, SDP, BPS and A-SDA) got the great majority of votes in areas dominantly populated by Bosniaks, four parties (SNSD, SDS, PDP-NDP and DNS) in the entity of Republika Srpska, and two parties (HDZ BiH and HDZ 1990) in municipalities with Croat majority. Secondarily, urban - rural, regional, social and ideological differences within the same ethno-political group are appearing, which additionally increases statistical and spatial heterogeneity of the elections results. Future research on this topic could reach a more exact data about the extent of congruence between the elections results and ethnic map after the 2013 census final results get published.

\section{REFERENCES}

[1] Cvrtila V., Politička geografija i geopolitika, Sveučilište u Zagrebu - Fakultet političkih znanonsti, Zagreb, 2004.

[2] Dejanović M., 22 godine višepartizma u Bosni i Hercegovini, Srbiji i Hrvatskoj, Rabic, Sarajevo, 2014.

[3] Glassner M. I., Political Geography - Second Edition, John Wiley \& Sons, Inc., New York, 1996.

[4] Klemenčić M., Izbori u Hrvatskoj 1990 - Elektoralnogeografska analiza odabranih primjera, Geografski glasnik, 53, 95 - 108, 1991.

[5] http://www.izbori.ba/Potvrdjeni2014/Finalni/ParlamentBIH/Default.aspx (10. 11. 2014.) 